\title{
МОЛОДІЖНИЙ ТУРИЗМ: ВИКОРИСТАННЯ ДОЗВІЛЛЕВОЇ ДІЯЛЬНОСТІ ДЛЯ РОЗВИТКУ ПРОФЕСІЙНИХ КОМПЕТЕНЦЙ У ПРАКТИЧНІЙ ПІДГОТОВЦІ МАЙБУТНІХ ФАХІВЦІВ ТУРИСТИЧНОӤ ГАЛУЗІ
}

\author{
Геращенко Я. М. \\ старший викладач кафедри підприємництва, менеджменту та туризму \\ Запорізький інститут економіки та інформаційних технологій \\ вул. Кияшка, 16Б, Запоріжжя, Украӥна \\ orcid.org/0000-0003-1327-2497 \\ yarinagerashchenko@ukr.net
}

\begin{abstract}
Ключові слова:
молодіжний туризм, дозвіллєва діяльність, підготовка фахівичів молодіжного туризму, професійні компетенції, професійні якості фахівия туризму.
\end{abstract}

У статті визначено важливість використання дозвіллєвої діяльності для розвитку професійних компетенцій у практичній підготовці майбутніх фахівців молодіжного туризму. Визначено необхідність у підготовці професійних кадрів туристичної галузі. Проаналізовано наукові публікації дослідників 3 питань практичної підготовки, дозвіллєвої діяльності та професійних компетенцій майбутніх фахівців туристичної галузі. Доведено вплив дозвіллєвої діяльності на розвиток професійних та особистісних якостей майбутніх організаторів молодіжного туризму. Сформульовано вміння фахівця молодіжного туризму, а саме: аналізувати сучасний ринок і тенденції розвитку молодіжного туризму; формувати сучасний та цікавий туристичний контент для молодої аудиторії мандрівників; розробляти нетипові туристичні маршрути для екскурсій та багатоденних мандрівок для молоді; просувати, рекламувати та реалізовувати туристичні продукти для молодоїаудиторії шляхом сучасних інформаційних технологій; вивчати конкурентів та вдосконалювати свою діяльність шляхом аналізу їх недоліків та досягнень. У статті упорядковано професійні та особистісні якості майбутнього фахівця 3 молодіжного туризму. Описано важливість розвитку пізнавального, ціннісного, творчого, комунікативного, соціального компонентів особистісного потенціалу майбутнього фахівця з молодіжного туризму продовжується в позааудиторний час. Запропоновані заходи організації дозвіллєвої діяльності («кураторська година», проведення молодіжних туристичних заходів, «круглий стіл»). Доведено, що процес педагогічної організації дозвіллєвої діяльності має підготовчий, проміжний та заключний етапи. У результаті детального аналізу та вивчення наукових публікації та нормативної документації зроблено висновок, що підготовка висококваліфікованих і конкурентоспроможних на ринку праці фахівців, здатних до компетентної, відповідальної і ефективної діяльності неможлива без педагогічного супроводу дозвіллєвої діяльності в процесі навчання в закладах вищої освіти. 


\title{
YOUTH TOURISM: USE OF LEISURE ACTIVITY FOR DEVELOPMENT OF PROFESSIONAL COMPETENCES IN PRACTICAL TRAINING OF FUTURE TOURIST PROFESSIONALS
}

\author{
Herashchenko Ya. M. \\ Senior Lecturer at the Department of Entrepreneurship, Management and Tourism \\ Zaporizhzhia Institute of Economics and Information Technologies \\ Kiyashka str., 16B, Zaporizhzhia, Ukraine \\ orcid.org/0000-0003-1327-2497 \\ yarinagerashchenko@ukr.net
}

\begin{abstract}
Key words:
youth tourism, leisure activity, training of youth tourism specialists, professional competencies, professional qualities of a tourism specialist.
\end{abstract}

\begin{abstract}
The article identifies the importance of using leisure activities for the development of professional competencies in the practical training of future youth tourism professionals. The need for training of professional staff of the tourism industry is determined. Scientific publications of researchers on practical training, leisure activities and professional competencies of future tourism professionals are analyzed. The influence of leisure activities on the development of professional and personal qualities of future organizers of youth tourism is proved. The skills of a youth tourism specialist are formulated, namely: to analyze the modern market and trends in the development of youth tourism; to form modern and interesting tourist content for a young audience of travelers; develop atypical tourist routes for excursions and multi-day trips for young people; to promote, advertise and sell tourism products for young audiences through modern information technologies; study competitors and improve their performance by analyzing their shortcomings and achievements. The article organizes the professional and personal qualities of the future specialist in youth tourism. The importance of the development of cognitive, value, creative, communicative, social components of the personal potential of the future specialist in youth tourism continues in extracurricular time. Measures of organization of leisure activities ("curatorial hour", carrying out of youth tourist actions, "round table") are offered. It is proved that the process of pedagogical organization of leisure activity has preparatory, intermediate and final stages. As a result of detailed analysis and study of scientific publications and regulations, it was concluded that the training of highly qualified and competitive in the labor market professionals capable of competent, responsible and effective activities is impossible without pedagogical support of leisure activities in higher education.
\end{abstract}

Постановка проблеми. Туризм $\epsilon$ високоефективною індустрією в економічному, соціальному та культурному розвитку країн. 3 огляду на стандарти і вимоги світового туристичного ринку нашій державі необхідно докладати зусилля щодо внутрішніх та зовнішніх перетворень в індустрії гостинності та туризму. Фундаментом цих перетворень є професійна підготовка майбутніх фахівців туристичної галузі в освітніх закладах.

Невіддільною частиною провадження освітньої діяльності є практична підготовка, яка є найефективнішим способом у підготовці висококваліфікованих кадрів туризму.

Питання практичної підготовки фахівців туризму висвітлювали у своїх роботах практики В. Федорченко, Л. Поважна, Н. Фоменко,
Г. Цехмінстрова, Г. Щука, Л. Польова, Л. Сакун, М. Скрипник та інші.

Наукові доробки таких вчених, як Т. Сокол, В. Лозовецька, О. Гура, В. Федорченко, О. Зуброва, були присвячені питанням розвитку професійних якостей майбутніх фахівців, зокрема у галузі туризму.

Процес педагогічної організації дозвіллєвої діяльності останніми роками набув нових смислів. Велика кількість науковців, зокрема I. Петрова, В. Бочелюки, Н. Яременко, I. Сидор та інші, досліджують педагогічні, соціокультурні, виховні завдання дозвіллєвої діяльності.

Вплив дозвіллєвої діяльності на розвиток особистісних та професійних якостей майбутніх фахівців-організаторів молодіжного туризму 
недостатньо розкрито, саме цей фактор став визначальним у виборі теми дослідження.

Мета статті полягає в огляді наукових публікацій, нормативної документації та вивченні практичного досвіду педагогів-практиків щодо питань практичної підготовки і застосування дозвіллєвої діяльності для розвитку професіоналізму майбутніх фахівців молодіжного туризму.

Виклад основного матеріалу дослідження. Становлення людини у суспільстві та їі індивідуальних проявів особистості відбувається під впливом певного середовища.

Вступаючи в 3ВО, студент потрапляє в освітній простір / середовище, яке формує його професійно, присвоює педагогічну та загальну культуру, сприяє становленню особистісно-орієнтованих відносин, життєвої позиції майбутнього фахівця [1].

Система науково-методичних та педагогічних заходів в освітньому процесі спрямована на передачу, засвоєння, примноження та використання знань, умінь і професійних компетентностей [2], тому у підготовці майбутніх фахівців молодіжного туризму важливу роль відіграють традиційні форми організації навчання: лекції, семінари, самостійні та практичні роботи.

Оволодіння професійними уміннями та навичками, сучасними методами та формами організації праці дають можливість майбутнім фахівцям туристичної галузі відчувати впевненість у власних силах і самостійність у вирішенні завдань в галузі їх майбутньої професії.

Невіддільним складником успішної підготовки студентів 3ВО - фахівців молодіжного туризму є закріплення отриманих теоретичних знань під час аудиторного навчання у практичній діяльності. Практична підготовка за напрямом «Туризм» відбувається під час практичної форми навчання, а саме проходження студентами практики - на підприємствах шляхом стажувань.

Практична підготовка $є$ важливим складником в освітньому процесі. Це організована діяльність 3 метою оволодіння певною спеціальністю [3, с. 579]; важлива форма організації навчального процесу, від якості якої залежить конкурентоздатність випускників вузів на ринку праці [4, с. 228].

Майбутні фахівці туристичної галузі під час практичної підготовки закріплюють знання із теоретичних дисциплін на практиці, засвоюють методи розв'язування виробничих проблем, поглиблюють професійні навички та уміння роботи в реальних виробничих умовах.

Відповідно до Постанови Кабінету Міністрів України поняття «уміння / навички» формуються як здатність застосовувати знання для виконання завдань та розв'язання проблем. Також у документі зазначено, що «уміння / навички» поділяються на когнітивні (що включають логічне, інтуїтивне та творче мислення) і практичні (що включають ручну вправність, застосування практичних способів (методів), матеріалів, знарядь та інструментів, комунікацію) [5].

Організатор молодіжного туризму, на нашу думку, повинен вміти: аналізувати сучасний ринок i тенденції розвитку молодіжного туризму; формувати сучасний та цікавий туристичний контент для молодої аудиторії мандрівників; розробляти нетипові туристичні маршрути для екскурсій та багатоденних мандрівок для молоді; просувати, рекламувати та реалізовувати туристичні продукти для молодої аудиторії шляхом сучасних інформаційних технологій; вивчати конкурентів та вдосконалювати свою діяльність шляхом аналізу їх недоліків та досягнень.

На результат практичної підготовки студентів значно впливають індивідуальні психічні, психомоторні і фізичні властивості, які під впливом фахової підготовки набувають професійності.

Професійні якості - це окремі динамічні властивості, які є одним із найважливіших чинників професійної придатності і не тільки характеризують певні здібності, але й органічно входять до їх структури, розвиваючись у процесі навчання й практичної діяльності [6, с. 128].

З огляду на вищевказане нами було упорядковано особисті та професійні якості майбутнього фахівця молодіжного туризму. До особистих якостей відносимо: енергійність, спритність; ерудованість, різнобічність; терпимість, інтерес і повага до людей; оригінальність, артистизм, творчість, почуття гумору; прагнення до саморозвитку; впевненість у собі, прийнятих рішеннях; цілеспрямованість, наполегливість, ініціативність; упорядкованість; наявність розвинутої інтуїції; спостережливість; тактовність, чуйність; вихованість.

До професійних якостей фахівця молодіжного туризму належать: комунікативні здібності; вербальні здібності; ораторські здібності; уміння слухати; розвинуті організаторські здібності; уміння приймати рішення в невизначених ситуаціях, фізична підготовка; здатність вирішувати проблемні ситуації в короткий термін; здатність керувати собою; гарний розвиток словесно-логічної й образної пам'яті; гарний розвиток мнемонічних здібностей; високий рівень розвитку переключення і розподілу уваги; здатність впливати на оточуючих.

Отже, сукупність знань, умінь, навичок і професійно-значущих якостей особистості визначають професійну компетенцію фахівця.

Професійно-компетентний фахівець здатний і готовий до продуктивної діяльності та орієнтований на самостійну активність у пізнавальних процесах під час виконання професійних функцій $[7$, с. 41]. 
Розвиток пізнавального, ціннісного, творчого, комунікативного, соціального компонентів особистісного потенціалу майбутнього фахівця 3 молодіжного туризму продовжується і в позааудиторний час. Студенти у свій вільний час задовольняють власні потреби, інтереси. Таку діяльність ми розуміємо як «дозвіллєва діяльність».

Дозвіллєва діяльність проявляється в добровільній, свідомій діяльності, відображає прагнення, інтереси людини, залежить від ії потреб та мотивів [8, с. 96].

Якість цієї діяльності залежить від культури та морального розвитку самої особистості, певних орієнтирів, які вона виробляє серед багатьох естетичних, моральних, політичних чи інших життевих цінностей $[9$, с. 44].

Освітнє середовище значно розширює свої кордони, виходить за межі ЗВО і має соціокультурний вплив на молодь і під час їх дозвіллєвої діяльності.

3 огляду на цю тенденцію ми вважаємо, що формування певних професійних якостей можливе і під час дозвіллєвої діяльності майбутніх фахівців туристичної галузі.

Ми згодні з тим, що педагогічний процес у сфері дозвілля становить цілеспрямовану організацію дозвіллєвої діяльності і потребує систематичного удосконалення 3 урахуванням характерних ознак та потреб особистості $[9$, с. 45].

Зарубіжні і вітчизняні науковці наголошують на необхідності виховувати у людини вміння раціонально використовувати свій вільний час та ефективно проводити своє дозвілля (П. Арен, $\Phi$. Мінне, А. Ріпер) і наголошують на тому, що основними складниками діяльності $є$ дієвість та різноманітність [9, с. 42].

3 огляду на педагогічну доцільність та фахову необхідність щодо підготовки майбутніх фахівців туристичної галузі до організації молодіжного туризму нами запропоновані заходи організації дозвіллєвої діяльності («кураторська година», проведення молодіжних туристичних заходів, «круглий стіл»).
Процес педагогічної організації дозвіллєвої діяльності має підготовчий, проміжний та заключний етапи.

Підготовчий етап вміщує: підготовку матеріалів педагога-куратора до, наприклад, «Кураторської години». Мета заходу: інформаційне знайомство студентів 3 різними видами дозвіллєвої діяльності фахової направленості; обговорення педагогічного потенціалу діяльності та можливості іiі реалізації.

Проміжний етап передбачає: організацію дозвілля та активну діяльнісну участь студентів у заходах, пов'язаних 3 молодіжним туризмом. На цьому етапі (особливо на першому курсі) дуже важливий особистий приклад, особиста участь у дозвіллєвій діяльності педагога-новатора, носія фаховості, професійності та культури.

На заключному етапі, наприклад, «Круглий стіл», організатори та учасники обговорюють моменти своєї дозвіллєвої діяльності: якісність організації, особиста корисність, ціннісні складники (інтелектуальне, моральне, духовне насичення). Особлива увага приділяється аналізу пізнавальної діяльності, під час якої студенти поглиблювали свої знання, уміння та навички, як майбутніх фахівців молодіжного туризму.

Висновки. Отже, підготовка висококваліфікованих і конкурентоспроможних на ринку праці фахівців, здатних до компетентної, відповідальної i ефективної діяльності, неможлива без педагогічного супроводу дозвіллєвої діяльності в процесі навчання в ЗВО.

Під час якісно організованої дозвіллєвої діяльності майбутні фахівці з молодіжного туризму професійно зростають, закріплюють свої знання, уміння, навички, особисті професійні якості.

Різноманітність видів дозвіллєвої діяльності дозволяе студентам опрацьовувати різні форми, методи і засоби для організації заходів.

Педагогічне супроводження дозвіллєвої діяльності формує ціннісні уявлення та орієнтації майбутніх фахівців з молодіжного туризму, підвищує їх освітній рівень.

\section{Література}

1. Мардахаев Л.В. Социальная педагогика : учебник. Москва : Гардарики, 2006. 269 с.

2. Про вищу освіту : Закон України від 9 серпня 2019 р. № 1556-VII / Верховна Рада України. URL: https://zakon.rada.gov.ua/laws/show/1556-18.

3. Дубічинський В.В. Сучасний тлумачний словник української мови : 60000 слів. Харків : ВД «ШКОЛА», 2008. $832 \mathrm{c}$.

4. Балабан П.Ю., М.П. Балабан, Ю.В. Іванов Практична підготовка як важлива складова навчального процесу. Якість вищої освіти: вдосконалення змісту та організації практичної підготовки студентів : матеріали XL Міжнародної наук.-метод. конф., м. Полтава, 25-26 лютого 2015 р. Полтава, 2015. C. 228-230.

5. Про затвердження Національної рамки кваліфікацій : Постанова від 23 листопада 2011 р. № 1341 / Кабінет Міністрів України. URL: https://zakon.rada.gov.ua/laws/show/1341-2011-n68. 
6. Сошенко С.М. Професійні якості як чинник успішності майбутнього психолога. Педагогічний процес: теорія і практика : Вип. 1., 2014. С. 126-130.

7. Методика викладання у вищій школі : навчальний посібник. О.В. Малихін, І.Г. Павленко, О.О. Лаврентьєва, Г.І. Матукова. Сімферополь : Дайфі, 2011. 270 с.

8. Власенко О.М. Дозвіллєва діяльність як фактор самореалізації студентів в освітньому середовищі закладу вищої освіти. Інноваиійна педагогіка : Вип. 4(2). 2018. С. 95-97.

9. Петрова І.В. Дозвілля в зарубіжних країнах : навчальний посібник. Київ : Кондор, 2005. 408 с.

\section{References}

1. Mardakhaev L.V. (2006) Sotsyalnaia pedahohyka : uchebnyk [Social pedagogy: textbook]. P. 269.

2. Pro vyshchu osvitu : Zakon Ukrainy vid 9 serpnia 2019 r. № 1556-VII / Verkhovna Rada Ukrainy. URL: https://zakon.rada.gov.ua/laws/show/1556-18

3. Dubichynskyi V.V. (2008) Suchasnyi tlumachnyi slovnyk ukrainskoi movy: 60000 sliv [Modern explanatory dictionary of the Ukrainian language: 60,000 words] P. 832.

4. Balaban P.Iu., M.P. Balaban, Yu.V. Ivanov (2015) Praktychna pidhotovka yak vazhlyva skladova navchalnoho protsesu [Practical training as an important component of the educational process] Quality of higher education: improving the content and organization of practical training of students. Vol. XL. pp. 228-230.

5. Pro zatverdzhennia Natsionalnoi ramky kvalifikatsii : Postanova vid 23 lystopada 2011 r. № 1341 / Kabinet Ministriv Ukrainy. URL: https://zakon.rada.gov.ua/laws/show/1341-2011-n68.

6. Soshenko S.M. (2014) Profesiini yakosti yak chynnyk uspishnosti maibutnoho psykholoha [Professional qualities as a factor in the success of the future psychologist] Pedagogical process: theory and practice. Vol. 1. pp. 126-130.

7. Malykhin O.V., Pavlenko I.H., Lavrentieva O.O., Matukova H.I. (2011) Metodyka vykladannia u vyshchii shkoli : navchalnyi posibnyk [Methods of teaching in high school: a textbook] P. 270.

8. Vlasenko O.M. (2018) Dozvillieva diialnist yak faktor samorealizatsii studentiv v osvitnomu seredovyshchi zakladu vyshchoi osvity [Leisure activities as a factor of self-realization of students in the educational environment of higher education] Innovative pedagogy. Vol. 4 (2). pp. 95-97.

9. Petrova I.V. (2005) Dozvillia v zarubizhnykh krainakh : navchalnyi posibnyk [Leisure in foreign countries: a textbook]. P. 408. 